OPEN ACCESS

Edited by:

Neil Martin O'Brien-Simpson, University of Melbourne, Australia

Reviewed by: George Kokotos, National and Kapodistrian University of Athens, Greece

Norelle Daly,

James Cook University, Australia

*Correspondence: Silverio García-Lara sgarcialara@itesm.mx

Specialty section: This article was submitted to Chemical Biology, a section of the journal Frontiers in Chemistry

Received: 07 April 2017 Accepted: 12 June 2017 Published: 21 June 2017

Citation: Díaz-Gómez JL, Castorena-Torres F, Preciado-Ortiz RE and García-Lara S (2017) Anti-Cancer Activity of Maize Bioactive Peptides. Front. Chem. 5:44.

doi: 10.3389/fchem.2017.00044

\section{Anti-Cancer Activity of Maize Bioactive Peptides}

\author{
Jorge L. Díaz-Gómez ${ }^{1}$, Fabiola Castorena-Torres ${ }^{2}$, Ricardo E. Preciado-Ortiz ${ }^{3}$ and \\ Silverio García-Lara ${ }^{1 *}$
}

${ }^{1}$ Agri-Foods Unit, Tecnologico de Monterrey, Monterrey, Mexico, ${ }^{2}$ Tecnologico de Monterrey, Escuela de Medicina, Monterrey, Mexico, ${ }^{3}$ Maize Breeding Program-INIFAP Campo Experimental Bajio, Celaya, México

Cancer is one of the main chronic degenerative diseases worldwide. In recent years, consumption of whole-grain cereals and their derivative food products has been associated with a reduced risk of various types of cancer. The main biomolecules in cereals include proteins, peptides, and amino acids, all of which are present in different quantities within the grain. Some of these peptides possess nutraceutical properties and exert biological effects that promote health and prevent cancer. In this review, we report the current status and advances in knowledge regarding the bioactive properties of maize peptides, such as antioxidant, antihypertensive, hepatoprotective, and antitumor activities. We also highlight the potential biological mechanisms through which maize bioactive peptides exert anti-cancer activity. Finally, we analyze and emphasize the potential applications of maize peptides.

Keywords: maize, disease, peptides, bioactive, antioxidant, anticancer, antihypertensive, hepatoprotective

\section{INTRODUCTION}

According to the World Health Organization, chronic diseases are currently the major cause of morbidity worldwide, and will become one of the major causes of mortality by the next decade (WHO, 2017). In recent years, the consistent consumption of cereals and cereal-derived food products has been linked with a reduced risk of cancer and other chronic degenerative diseases. Several reports indicate that diets rich in whole-grain cereals are associated with lower cancer mortality rates, particularly colon, breast, and prostate cancers. (Jeong et al., 2003; Liu, 2007).

Cereals contain nutraceutical molecules that can exert specific biological effects and promote health and prevent diseases (Chaturvedi et al., 2011). These biomolecules are proteins and their derivatives, peptides, and amino acids present in different quantities in the grain. Legumes such as soybean are the most studied source of bioactive proteins and peptides due to their high (up to $40 \%$ ) average protein content (Cavazos and Gonzalez de Mejia, 2013). Cereals such as wheat, rice, barley, rye, and maize have been recently identified as new sources of bioactive peptides. High quality cereal proteins are an important source of bioactive peptides, which consist of distinctive amino acid sequences, and which, once they are released, could display diverse functionalities (de Mejia et al., 2012; Zambrowicz et al., 2013). Cereal bioactive peptides have been a part of the human diet for centuries. In addition to their nutritional roles, these peptides could perform biological activities (Dia and Mejia, 2010).

The potential therapeutic use of peptides derived from food has been discussed previously (Malaguti et al., 2014; Ortiz-Martinez et al., 2014), and these peptides have displayed a broad range of effects in different models (McDermott, 2009). The main objective of this review was to report the current status and advances in knowledge regarding the bioactive properties of maize peptides, and 
to review the evidence relating to the identification, characterization, and relevance of the biological activities through which these peptides exert an anti-cancer effect.

\section{MAIZE AS A SOURCE OF BIOACTIVE PEPTIDES}

Cereals, which are members of the grass family Gramineae, are the most important source of foods for the world population, and the main source of carbohydrates, proteins, vitamins, and minerals. Maize, rice, and wheat are the most important grains in the human diet, and with more than 1,000 million tons harvested in 2014, maize is the most popular crop worldwide (FAO, 2015).

A maize kernel consists of an embryo (or germ), an endosperm packed with starch grains, and bran (fiber). The most abundant kernel nutrient is starch, which is composed mainly of amylopectin and amylose (72-73\% of the total kernel weight), followed by proteins that represent $\sim 8-12 \%$ of the total kernel weight (FAO, 1992). The essential amino acid content is $\sim 5-10 \%$ lower than the non-essential amino acid content, with glutamic acid being the most abundant amino acid (Tang et al., 2013). Four groups of storage proteins are present in maize kernels: albumins, globulins, prolamins, and glutelins. Albumins and globulins are found mainly in the germ, while prolamins and glutelins are found predominantly in the endosperm (Shukla and Cheryan, 2001). These four classes are also categorized according to their solubility: water-soluble albumins, globulins soluble in salt solution, prolamins soluble in alcoholic, and glutelins insoluble in neutral aqueous or saline solutions and ethanol. Globulins and albumins regulate and control grain metabolism, whereas prolamins and glutelins store the nitrogen necessary for seed germination (Anderson and Lamsal, 2011).

In terms of quantity, the protein content of maize kernels is composed mostly of prolamins or zeins (40\%), followed by glutelins (30\%), with globulins and albumins found in lesser quantities (5\%) (Wang et al., 2008). Zeins are mainly found in protein bodies in the rough endoplasmic reticulum and constitute $\sim 44-79 \%$ of maize endosperm proteins (Giuberti et al., 2012). Zeins are devoid of lysine and tryptophan, amino acids that are essential for human survival (Huang et al., 2004). Zeins are composed of four fractions: $\alpha, \gamma, \beta$, and $\delta$; $\alpha$-zeins represent $71-85 \%$ of the prolamins in the grain, whereas $\gamma-, \beta$-, and $\delta$-zeins represent 20,5 , and $5 \%$ of the prolamins in the grain, respectively. Therefore, $\alpha$-zein is the most important fraction because it stores most of the nitrogen (Momany et al., 2006). A structural representation and the amino acid sequence of $\alpha$ zein are shown in Figure 1. The molecular weights of the four fractions are as follows: $\alpha, 19$ and $22 \mathrm{kDa} ; \gamma, 18$ and $27 \mathrm{kDa} \beta$, $16 \mathrm{kDa}$; and $\delta, 10 \mathrm{kDa}$ (Anderson and Lamsal, 2011). Another $\alpha$ zein fraction with a molecular weight of $24 \mathrm{kDa}$ contains a defective signal peptide that induces the incorrect formation of zein bodies in the cell. This variant is present in the floury-2 (fl2) maize mutants that have higher content of the essential amino acid lysine in the endosperm, and this mutation leads to the synthesis of the $\alpha$-zein variant and the defective signal peptide (Coleman et al., 1995). The most abundant amino acids found in these fractions are glutamic acid, leucine, proline, and alanine (Kong and Xiong, 2006).

Albumins are richer in aspartate, asparagine, threonine, glycine, alanine, proline, and half-cystine, but have low histidine, arginine, glutamic acid, glutamine, and phenylalanine content (Landry and Moureaux, 1987). Glutelins are alkali-soluble proteins with molecular weights of $10,15,18$, and $27 \mathrm{kDa}$; they are present in protein bodies along with zeins, and their amino acid composition and function is similar to that of zeins (Wall et al., 1988).

\section{Bioactive Peptides Properties}

In general, cereal-derived peptides have been shown to possess opiate, antithrombotic, anticancer, antihypertensive, immunomodulatory, mineral-binding, antimicrobial, and antioxidant properties (de Mejia et al., 2012). Various bioactive peptides have been found and reported in maize (Tnani et al., 2013; Li et al., 2014). Maize bioactive peptides are obtained by the hydrolysis of kernels and sub-products. Among the different techniques for peptide generation, enzymatic hydrolysis is the most widely used method for maize. The main enzymes used in the hydrolysis of maize protein are listed in Table $\mathbf{1 .}$ For bioactivity evaluations, peptides have been fractionated by ultra-filtration (Wang Y. et al., 2014; Jin et al., 2016), and separated using chromatographic techniques with multiple purification steps (Puchalska et al., 2013; Wang X.-J. et al., 2014; Jin et al., 2016; Wang et al., 2016) to obtain low molecular weight peptides that have shown promise in further characterization. Various bioactive properties of maize peptides have been reported, including anticancer activity and other activities that have beneficial effects on health, such as antioxidant, antihypertensive, hepatoprotective, and alcohol protective activities. The different studies reporting the bioactive properties of maize peptides are listed in Table $\mathbf{1}$.

\section{HEALTH EFFECTS OF MAIZE PEPTIDES}

\section{Anticancer}

In the past few years, an important advance in cereal peptides research has been the finding that novel cereal-derived proteins and peptides exert preventive effects in different stages of cancer, including initiation, promotion, and progression. Because of the urgent need for effective cancer prevention therapy, chemoprevention has emerged as a viable anti-cancer approach. Chemo-preventive agents are expected to be safe, inexpensive, and abundant. Peptides fulfill these criteria, and are considered to be safer than synthetic compounds as they are present in the regular human diet and have a wide range of availability and acceptability (Li et al., 2014). Several studies have shown the anticancer potential of dietary proteins, peptides, and amino acids in the regulation of apoptosis and angiogenesis, important steps in controlling tumor metastasis; these molecules are naturally occurring or generated by fermentation, enzymatic hydrolysis, or gastrointestinal digestion (de Mejia and Dia, 2010).

Bioactive peptides exert anti-tumor activity via several key mechanisms: (a) Apoptosis induction, which involves an energydependent cascade mediated via specific proteases or caspases; 


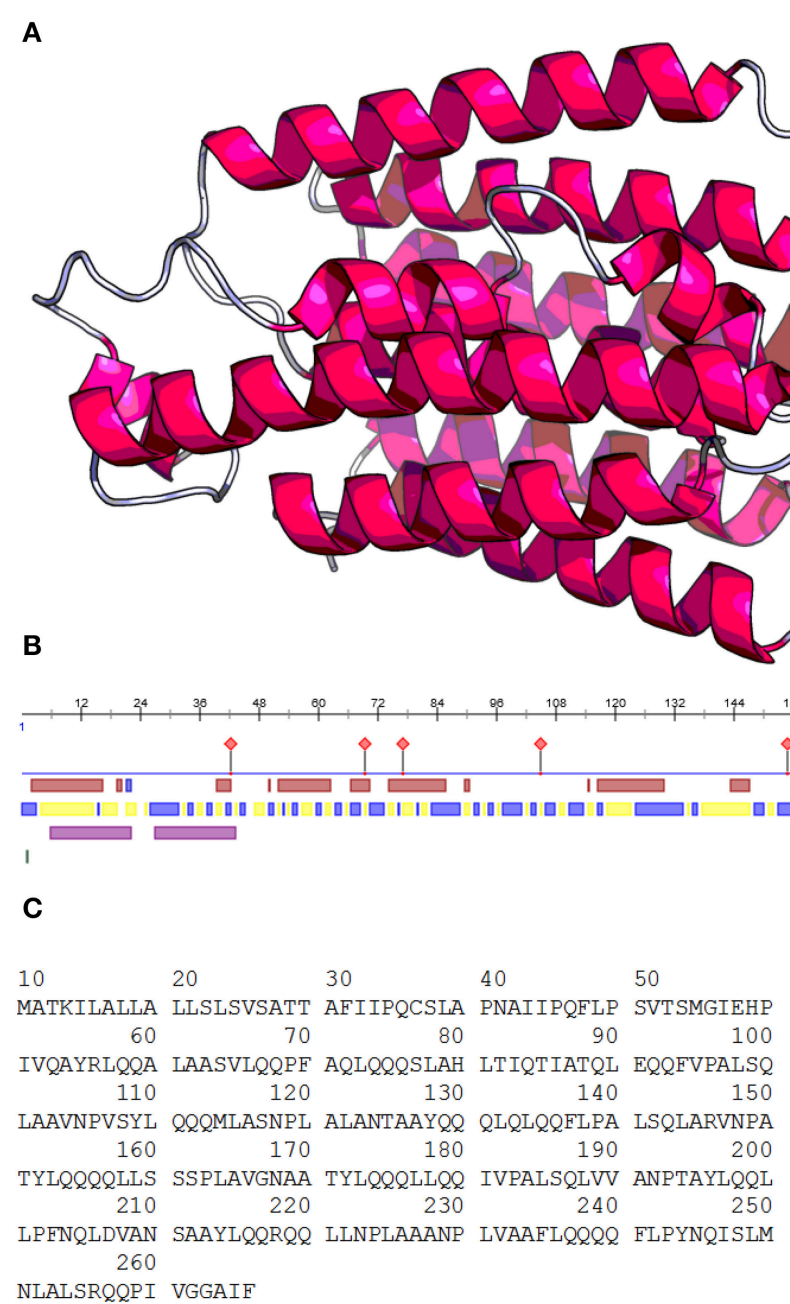

FIGURE 1 | Structure prediction of $\alpha$-zein 22 kDa (A). Zein regions (B): protein binding regions $(\diamond)$, helix ( $\square$ ), exposed region ( $\square)$, buried region ( ), helical transmembrane region $(\square)$, disordered region $(\square)$. Zein amino acid sequence (C). Images obtained using prediction web programs PredictProtein and RaptorX (Rost, 2003; Källberg et al., 2012).

strategies to overcome tumor resistance to apoptotic pathways include activation of pro-apoptotic receptors, restoration of p53 activity, caspase modulation, and proteasome inhibition (Burz et al., 2009). (b) Blockade of intermediate tumor generation by regulating cellular mechanisms associated with cell proliferation and survival, or biosynthetic pathways that control cell growth (Kornienko et al., 2013). (c) Regulation of immune system function by increasing the expression of tumor-associated antigens (antigenicity) in cancer cells, by triggering tumor cells to release danger signals that stimulate immune responses (immunogenicity), or by increasing the predisposition of tumor cells to be recognized and killed by the immune system (susceptibility) (Zitvogel et al., 2013).

The anticancer activities of different peptides have been characterized, with most of them showing pro-apoptotic activity (Dia and Mejia, 2010; Gonzalez de Mejia et al., 2010; Dia and Gonzalez, 2011; McConnell et al., 2015). Some mechanisms proposed for the anticancer activity of peptides are autophagy and apoptosis (de Mejia and Dia, 2010; Hernandez-Ledesma et al., 2013), and maize peptides may promote these processes in different cancer cells.

A primary anticancer effect of maize peptides has been demonstrated using in vitro models. HepG2 cells showed an increase in apoptotic activity when they were exposed to maize peptides obtained by enzymatic hydrolysis of protein extracted from corn gluten meal (Li et al., 2013). In that study, maize peptides were also evaluated in H22-tumor bearing mice. Treatment of animals with these peptides at a dose of $400 \mathrm{mg} / \mathrm{kg}$ resulted in an inhibition of tumor growth. Moreover, the administration of maize peptides enhanced immune system activity compared with that in the control group.

More recently, a study by Ortiz-Martinez et al. (2017) revealed important anti-cancer effects of maize peptides in HepG2 cells. 
TABLE 1 | Main bioactivities of maize peptides, and methods used for their enzymatic hydrolysis fractionation.

\begin{tabular}{|c|c|c|c|c|}
\hline Type of bioactivity & Bioactivity measured & Enzyme used & $\begin{array}{l}\text { Use of } \\
\text { ultrafiltration/ } \\
\text { chromatografy }\end{array}$ & References \\
\hline \multirow[t]{13}{*}{ Anti-Oxidant } & Inhibition of pyrogallol oxidation & Alcalase & $\mathrm{N} / \mathrm{Y}$ & Zheng et al., 2006 \\
\hline & Inhibition of lipid peroxidation, reducing power, scavenging activity & Alcalase & $\mathrm{N} / \mathrm{Y}$ & Li et al., 2008 \\
\hline & $\begin{array}{l}\text { Radical scavenging, removal of superoxide anion, inhibition of lipid } \\
\text { peroxidation, reducing power }\end{array}$ & Alcalase & $\mathrm{N} / \mathrm{Y}$ & Li et al., 2010 \\
\hline & Radical scavenging & Alcalase & $Y / Y$ & Tang et al., 2010 \\
\hline & Scavenging activity & None & $\mathrm{N} / \mathrm{N}$ & Zhang et al., 2011 \\
\hline & $\begin{array}{l}\text { Oxygen radical absorbance, scavenging activity, chelating activity, } \\
\text { inhibition of lipid peroxidation }\end{array}$ & $\begin{array}{l}\text { Neutral protease, alkaline } \\
\text { protease, protease validase }\end{array}$ & $\mathrm{Y} / \mathrm{N}$ & Zhou et al., 2012 \\
\hline & $\begin{array}{l}\text { Scavenging activity of different radicals, chelating activity, inhibition } \\
\text { of lipid peroxidation }\end{array}$ & Alkaline protease, flavourzyme & $\mathrm{Y} / \mathrm{Y}$ & Zhuang et al., 2013 \\
\hline & Scavenging activity, chelating activity, reducing power, & $\begin{array}{l}\text { Alkaline protease, trypsin, } \\
\text { papain, flavourzyme }\end{array}$ & $\mathrm{Y} / \mathrm{Y}$ & Tang and Zhuang, 2014 \\
\hline & Scavenging activity, chelating activity, reducing power & Alcalase & $\mathrm{Y} / \mathrm{Y}$ & Wang X.-J. et al., 2014 \\
\hline & Scavenging activity, reducing power & Alkaline protease & $\mathrm{Y} / \mathrm{Y}$ & Zhou et al., 2015 \\
\hline & $\begin{array}{l}\text { Scavenging activity, oxygen radical absorbance, antioxidant effect } \\
\text { in HepG2 and } \mathrm{Caco} 2 \text { cells }\end{array}$ & Alcalase & $\mathrm{Y} / \mathrm{N}$ & Wang et al., 2015 \\
\hline & Scavenging activity, chelating activity, reducing power & Alcalase, flavourzyme & $\mathrm{Y} / \mathrm{Y}$ & Jin et al., 2016 \\
\hline & $\begin{array}{l}\text { Scavenging activity, inhibition of aggregation and oligomerization } \\
\text { of } A \beta \text { peptides in Caenorhabditis elegans }\end{array}$ & Alcalase & $\mathrm{N} / \mathrm{Y}$ & Zhang et al., 2016 \\
\hline \multirow[t]{6}{*}{ Anti-Hypertensive } & $\begin{array}{l}\text { Inhibitory activity of ACE, decrease of blood pressure in an animal } \\
\text { model }\end{array}$ & Trypsin & $Y / Y$ & Yang et al., 2007 \\
\hline & Inhibitory activity of ACE & $\begin{array}{l}\text { Trypsin, thermolysin, } \\
\text { flavourzyme, fungal protease }\end{array}$ & $\mathrm{Y} / \mathrm{N}$ & Parris et al., 2008 \\
\hline & $\begin{array}{l}\text { Inhibitory activity of ACE, decrease of blood pressure in an animal } \\
\text { model }\end{array}$ & Alcalase & $\mathrm{Y} / \mathrm{N}$ & Huang et al., 2011 \\
\hline & $\begin{array}{l}\text { Inhibitory activity of ACE, decrease of blood pressure in an animal } \\
\text { model }\end{array}$ & Alcalase & $Y / Y$ & Lin et al., 2011 \\
\hline & Inhibitory activity of ACE & Neutral protease & $\mathrm{N} / \mathrm{N}$ & Zhou et al., 2013 \\
\hline & Inhibitory activity of ACE & Thermolysin & $Y / Y$ & Puchalska et al., 2013 \\
\hline \multirow[t]{7}{*}{ Hepato-Protective } & $\begin{array}{l}\text { Changes in hepatic enzyme levels, histopathological changes in } \\
\text { hepatic tissue }\end{array}$ & Alcalase, neutral protease & $\mathrm{N} / \mathrm{N}$ & Guo et al., 2009 \\
\hline & $\begin{array}{l}\text { Changes in hepatic enzyme levels, histopathological changes in } \\
\text { hepatic tissue }\end{array}$ & Alcalase & $\mathrm{Y} / \mathrm{N}$ & Yu et al., 2012 \\
\hline & Decrease in alcohol blood concentration in an animal model & Alcalase & $Y / Y$ & Ma et al., 2012 \\
\hline & $\begin{array}{l}\text { Decrease in alcohol blood concentration in an animal model, } \\
\text { changes in hepatic enzyme levels }\end{array}$ & Alcalase & $\mathrm{Y} / \mathrm{N}$ & Yu et al., 2013 \\
\hline & $\begin{array}{l}\text { Changes in hepatic enzyme levels, histopathological changes in } \\
\text { hepatic tissue, }\end{array}$ & Alcalase & $\mathrm{Y} / \mathrm{Y}$ & Lv et al., 2013 \\
\hline & Changes in hepatic enzyme levels in a clinical trial & Alcalase & $\mathrm{Y} / \mathrm{N}$ & Wu et al., 2014 \\
\hline & Changes in hepatic enzyme levels, inhibition of apoptosis & Alcalase & $\mathrm{Y} / \mathrm{N}$ & Ma et al., 2015 \\
\hline \multirow[t]{2}{*}{ Anti-Cancer } & $\begin{array}{l}\text { Apoptosis induction in a HepG2 cell line, reduction of hepatic } \\
\text { tumor growth in an animal model, stimulation of the immune } \\
\text { system }\end{array}$ & Alcalase & $\mathrm{Y} / \mathrm{N}$ & Li et al., 2013 \\
\hline & $\begin{array}{l}\text { Antiprofilerative, modulation of cell cycle and apoptosis induction } \\
\text { in a HepG2 cell line. }\end{array}$ & Alcalase & $Y / Y$ & $\begin{array}{l}\text { Ortiz-Martinez et al., } \\
2017\end{array}$ \\
\hline Antimicrobial & $\begin{array}{l}\text { Growth inhibition in vitro in bacetria and fungi (Inhibition of spore } \\
\text { germination, hyphal elongation) }\end{array}$ & $\begin{array}{l}\text { Trypsin, endoproteinase Glu-C, } \\
\text { thermolysin }\end{array}$ & Y & Duvick et al., 1992 \\
\hline
\end{tabular}

Peptide fractions isolated from albumin Alcalase hydrolysates from normal maize were stronger than the ones from quality protein maize. The treatment of HepG2 cells with this peptide fraction from the different maize varieties increased the apoptosis induction rates an average of 4 -fold. These results suggested that the antiproliferative effect of peptide fractions isolated from both 
varieties was based on the induction of apoptosis due to the decrease in antiapoptotic factor expression.

\section{Antioxidant}

Antioxidant capacity is the main reported biological activity of maize peptides. This activity is explained by the presence of specific amino acids with radical scavenging and reducing capacities, such as lysine, tyrosine, phenylalanine, proline, alanine, histidine, and leucine (Zhou et al., 2015). Several peptides with antioxidant activity have been identified; however, their antioxidant potential depends on the enzymatic process used to obtain them. Zheng et al. (2006) studied the antioxidant capacity of peptides obtained using an optimized enzymatic hydrolysis process. Peptides with low molecular weight $(<5$ $\mathrm{kDa}$ ) exhibited higher antioxidant activity (Li et al., 2008; Zhou et al., 2012; Zhuang et al., 2013; Tang and Zhuang, 2014). The properties of these small peptides included hydroxyl radical and free radical scavenging activity, inhibition of lipid peroxidation, and ion chelating capacity. The antioxidant potential is not altered in peptides obtained from total protein or zein fraction ( $\mathrm{Li}$ et al., 2010; Tang et al., 2010). Another factor affecting antioxidant activity is the $\mathrm{pH}$ : native $\alpha$-zein has more antioxidant activity than $\alpha$-zein extracted in less basic or acidic conditions (Zhang et al., 2011). Synthesized peptides also show similar antioxidant activities (Wang X.-J. et al., 2014; Jin et al., 2016).

Additionally, peptides smaller than $3 \mathrm{kDa}$ have shown potent antioxidant activity in in vitro assays in HepG2 and Caco 2 cells exposed to high oxidative stress (Wang et al., 2015). Maize peptides also enhance the activity of cellular enzymes, and therefore, may exert preventive effects against cell damage via their antioxidant activity (Wang et al., 2016). Furthermore, in studies conducted in macrophage models, maize peptides have shown anti-inflammatory effects (Hernández-Ledesma et al., 2009; Cam and Gonzalez, 2012), which could have been exerted via their antioxidant properties. Oxidative stress has been shown to induce lipid peroxidation, protein oxidation, and DNA damage, subsequently causing mutant cell proliferation and finally, carcinogenesis (Thanan et al., 2014). These properties are relevant because of the relationship between oxidative stress and degenerative processes like carcinogenesis. Therefore, the antioxidant activity of maize peptides could be beneficial for cancer treatment.

\section{Antihypertensive}

Maize peptides have shown antihypertensive effects. A single peptide with an Ala-Tyr sequence, obtained from corn gluten meal, which is a main by-product of maize wet milling, showed significant inhibitory activity against angiotensin I-converting enzyme (Yang et al., 2007; Lin et al., 2011). Moreover, the same peptide has shown antihypertensive activity in spontaneously hypertensive rats with a minimum effective oral dose of $50 \mathrm{mg} / \mathrm{kg}$ resulting in a diastolic blood pressure reduction of $9.5 \mathrm{~mm} \mathrm{Hg}$ (Yang et al., 2007), and with an oral dose of $450 \mathrm{mg} / \mathrm{kg}$ resulting in a reduction of $40 \mathrm{mmHg}$ (Lin et al., 2011). In another report, peptides smaller than $3 \mathrm{kDa}$ showed greater blood pressure reductions (up to $34.45 \mathrm{mmHg}$ ) at a dose of $100 \mathrm{mg} / \mathrm{kg}$ in a spontaneously hypertensive rat model (Huang et al., 2011). These results show that molecular weight influences antihypertensive activity, with peptides smaller than $1 \mathrm{KDa}$ being the most active. In addition, enzymes used for protein hydrolysis and peptide generation also influence the antioxidant activity of the resulting peptides, with peptides obtained using trypsin and thermolysin being the most potent (Parris et al., 2008). In addition, ultrasonic treatment applied to corn gluten meal proteins before hydrolysis appears to increase the antihypertensive activity of the resulting peptides (Zhou et al., 2013). Antihypertensive peptides have been isolated and identified as LRP (leucine-arginine-proline), LSP (leucine-serine-proline), and LQP (leucine-glutamine-proline) by using high-performance liquid chromatography (Puchalska et al., 2013). Hence, molecular interactions of peptides can affect enzymes responsible for vascular hemodynamics, suggesting further potential applications for these enzymes.

\section{Hepatoprotective}

Recent studies have shown that maize peptides exert a protective effect by reducing damage to hepatic tissue. Using rats with liver damage induced by exposure to lipopolysaccharides from bacillus Calmette-Guérin, Guo et al. (2009) showed that administration of $600 \mathrm{mg} / \mathrm{kg}$ peptide significantly lowered the level of cell necrosis, hepatic lesions, and enzymes indicative of liver damage compared to that in control rats. In this study, the peptides protective effect on liver cells could be attributable to their antioxidant capacity. Maize peptides smaller than $5 \mathrm{kDa}$ exerted a hepatoprotective effect in a mouse model of carbon tetrachlorideinduced hepatic damage. At a dose of $200 \mathrm{mg} / \mathrm{kg}$, these peptides altered hepatic enzyme levels, lowering aspartate transaminase and alanine transaminase, and elevating superoxide dismutase and glutathione (Yu et al., 2012). Maize peptides may also exert a hepatoprotective effect by facilitating alcohol metabolism. Peptides as small as five amino acids have been shown to display this activity in mice (Ma et al., 2012). This effect is explained by the presence of leucine, which maintains the tricarboxylic acid cycle by supplying NAD+ (antioxidant effect). The same small peptide shown anti-apoptotic activity in mouse liver cells treated with alcohol to induce damage (Ma et al., 2015). A similar study found a hepatoprotective effect in mice at a dose of 200 $\mathrm{mg} / \mathrm{kg}$ with peptides smaller than $5 \mathrm{kDa}$, which resulted in lower blood alcohol concentrations (Yu et al., 2013). Maize peptides have also shown protective activity against hepatic fibrosis. In rats exposed to thioacetamide, which induces hepatic fibrosis, the minimum protective dose was $100 \mathrm{mg} / \mathrm{kg}$ (Lv et al., 2013). These studies demonstrate the hepatoprotective effect and mechanisms of action of maize peptides in response to different types of stress, suggesting another possible field of therapeutic application.

\section{Other Properties}

In addition to the effects discussed so far, a few more bioactive properties of maize peptides have been identified. Maize basic peptide 1 (BMP-1), which was obtained through protein hydrolysis, identified, and later synthetized, was shown to exert antimicrobial activity, inhibiting the growth of fungi and bacteria (Duvick et al. 1992). In an in vivo study in Caenorhabditis elegans, Zhang et al. (2016) demonstrated that a bioactive maize tetrapeptide possessed scavenging activity against intracellular 
reactive oxygen species. Additionally, this tetrapeptide inhibited the aggregation and oligomerization of $\beta$-amyloid peptide, which are involved in the development of Alzheimer's disease. These studies indicate the different bioactivities of maize peptides, which warrant further study and may be beneficial in the treatment of different diseases.

\section{THERAPEUTIC PERSPECTIVES AND CONCLUSIONS}

Peptides have attracted attention as drug candidates because they offer certain key advantages over alternative molecules. In contrast to traditional drugs, peptides have high affinity, strong specificity, low toxicity, and adequate tissue penetration. The therapeutic use of peptides has remained limited because of their high instability in biological environments, rapid depuration from the blood, poor membrane transportability, and effective digestion in the gastrointestinal tract (Sarmadi and Ismail, 2010). Peptide-based therapy depends on the ability of the peptide to remain intact until it reaches the target organ. Bioactive peptides must remain active and intact during gastrointestinal digestion and absorption to reach the cardiovascular system and potentially exert their physiological effects (Bhutia and Maiti, 2008).

Evidence supports the use of maize peptides as therapeutic molecules against a broad array of diseases linked to oxidative damage, such as cancer. In vitro models have been useful to investigate the antihypertensive and anticancer effects of maize peptides. However, in addition to in vitro evidence, in vivo experiments and clinical trials are needed to demonstrate the physiological effects of peptides. Few clinical trials have been conducted involving peptides and cancer (Gustafsson et al.,

\section{REFERENCES}

Anderson, T. J., and Lamsal, B. P. (2011). Zein extraction from corn, corn products, and coproducts and modifications for various applications: a review. Cereal Chem. 88, 159-173. doi: 10.1094/CCHEM-06-10-0091

Bhutia, S. K., and Maiti, T. K. (2008). Targeting tumors with peptides from natural sources. Trends Biotechnol. 26, 210-217. doi: 10.1016/j.tibtech.2008.01.002

Bouglé, D., and Bouhallab, S. (2017). Dietary bioactive peptides: human studies. Crit. Rev. Food Sci. Nutr. 57, 335-343. doi: 10.1080/10408398.2013.873766

Burz, C., Berindan-Neagoe, I., Balacescu, O., and Irimie, A. (2009). Apoptosis in cancer: key molecular signaling pathways and therapy targets. Acta Oncol. 48, 811-821. doi: 10.1080/02841860902974175

Cam, A., and Gonzalez M. E. (2012). RGD-Peptide lunasin inhibits Aktmediated NF-kB activation in human macrophages through interaction with the $\alpha$ V $\beta 3$ Integrin. Mol. Nutr. Food Res. 56, 1569-1581. doi: 10.1002/mnfr.201 200301

Cavazos, A., and Gonzalez de Mejia, E. (2013). Identification of bioactive peptides from cereal storage proteins and their potential role in prevention of chronic diseases. Compr. Rev. Food Sci. Food Safety 12, 364-380. doi: 10.1111/1541-4337.12017

Chaturvedi, N., Sharma, P., Shukla, K., Singh, R., and Yadav, S. (2011). Cereals nutraceuticals, health ennoblement and diseases obviation: a comprehensive review. J. Appl. Pharm. Sci. 1, 6-12.

Coleman, C. E., Lopes, M. A., Gillikin, J. W., Boston, R. S., and Larkins, B. A. (1995). A defective signal peptide in the maize high-lysine mutant floury 2. Proc. Natl. Acad. Sci.U.S.A. 92, 6828-6831. doi: 10.1073/pnas.92.1 5.6828
2004). Some synthetized peptides derived from seaproducts are being tested in phase II trials, these include: BioPep, Plitidepsin, Elisidepsin, and Tasidotin (Bouglé and Bouhallab, 2017). Even so this studies indicate that there is an enormous potential in the bioactivity of peptides derived from foods for the prevention and/or treatment of cancer. Also, there is an important opportunity for maize peptides with anticancer activity in diverse cancer cell lines as well as in different animal models that represent different carcinomas. In a future, the clinical efficacy will likely require intervention at several levels, and is necessary to test to evaluate their safety in short and long-term in vivo models and clinical trials on a large and heterogeneous populations.

\section{AUTHOR CONTRIBUTIONS}

All authors contributed equally to this work in terms of writing and conception. All authors wrote and reviewed the latest version of this manuscript.

\section{FUNDING}

This research was supported by the Research Nutriomics Chair Funds and CAT-005 from Tecnologico de Monterrey, Escuela de Ingeniería y Ciencias, as well as a Ph.D. scholarship presented to JD by CONACyT, Mexico.

\section{ACKNOWLEDGMENTS}

Special thanks to Mariana Zavala, Veronica Rocha providing manuscript internal revision and the external reviewers.

de Mejia, E. G., and Dia, V. P. (2010). The role of nutraceutical proteins and peptides in apoptosis, angiogenesis, and metastasis of cancer cells. Cancer Metastasis Rev. 29, 511-528. doi: 10.1007/s10555-010-9241-4

de Mejia, E., Martinez-Villaluenga, C., Fernandez, D., Urado, D., and Sato, K. (2012). "Bioavailability and safety of food peptides," in Food Proteins and Peptides, eds N. S. Hettiarachchy, K. Sato, M. R. Marshall, and A. Kannan (Boca Raton, FL: CRC Press), 297-330.

Dia, V. P., and Gonzalez M. E. (2011). Lunasin induces apoptosis and modifies the expression of genes associated with extracellular matrix and cell adhesion in human metastatic colon cancer cells. Mol. Nutr. Food Res. 55, 623-634. doi: $10.1002 / \mathrm{mnfr} .201000419$

Dia, V. P., and Mejia, E. G. (2010). Lunasin promotes apoptosis in human colon cancer cells by mitochondrial pathway activation and induction of nuclear clusterin expression. Cancer Lett. 295, 44-53. doi: 10.1016/j.canlet.2010.02.010

Duvick, J. P., Rood, T., Gurura Rao, A., and Marshak, D. R. (1992). Purification and characterization of a novel antimicrobial peptide from maize (Zea Mays L.) Kernels. J. Biol. Chem. 267, 18814-18820.

FAO (1992). Maize in Human Nutrition. Available online at: http://www.fao.org/docrep/t0395e/t0395e03.htm.

FAO (2015). FAOSTAT. Available online at: http://www.fao.org/faostat/en/\#data/QC

Giuberti, G., Gallo, A., and Masoero, F. (2012). Technical note: quantification of zeins from corn, high-moisture corn, and corn silage using a turbidimetric method: comparative efficiencies of isopropyl and tert-butyl alcohols. J. Dairy Sci. 95, 3384-3389. doi: 10.3168/jds.2011-4995

Gonzalez de Mejia, E., Wang, W., and Dia, V. P. (2010). Lunasin, with an arginine-glycine-aspartic acid motif, causes apoptosis to 11210 leukemia 
cells by activation of caspase-3. Mol. Nutr. Food Res. 54, 406-414. doi: 10.1002/mnfr.200900073

Guo, H., Sun, J., He, H., Yu, G. C., and Du, J. (2009). Antihepatotoxic effect of corn peptides against bacillus calmette-guerin/lipopolysaccharideinduced liver injury in mice. Food Chem. Toxicol. 47, 2431-2435. doi: 10.1016/j.fct.2009.06.041

Gustafsson, L., Leijonhufvud, I., Aronsson, A., Mossberg, A., and Svanborg, C. (2004). Treatment of skin papillomas with topical a-lactalbumin-oleic acid. $N$. Engl. J. Med. 350, 2663-2672. doi: 10.1056/NEJMoa032454

Hernandez-Ledesma, B., Hsieh, C. C., and de Lumen, B. O. (2013). Chemopreventive properties of peptide lunasin: a review. Protein Pept. Lett. 20, 424-432. doi: 10.2174/0929866511320040006

Hernández-Ledesma, B., Hsieh, C.-C., and de Lumen, B. O. (2009). Antioxidant and anti-inflammatory properties of cancer preventive peptide lunasin in RAW 264.7 macrophages. Biochem. Biophys. Res. Commun. 390, 803-808. doi: $10.1016 /$ j.bbrc.2009.10.053

Huang, S., Adams, W. R., Zhou, Q., Malloy, K. P., Voyles, D. A., Anthony, J., et al. (2004). Improving nutritional quality of maize proteins by expressing sense and antisense zein genes. J. Agric. Food Chem. 52, 1958-1964. doi: $10.1021 /$ jf0342223

Huang, W. H., Sun, J., He, H., Dong, H. W., and Li, J. T. (2011). Antihypertensive effect of corn peptides, produced by a continuous production in enzymatic membrane reactor, in spontaneously hypertensive rats. Food Chem. 128, 968-973. doi: 10.1016/j.foodchem.2011.03.127

Jeong, H. J., Park, J. H., Lam, Y., and De Lumen, B. O. (2003). Characterization of lunasin isolated from soybean. J. Agric. Food Chem. 51, 7901-7906. doi: $10.1021 /$ jf034460y

Jin, D. X., Liu, X. L., Zheng, X. Q., Wang, X. J., and He, J. F. (2016). Preparation of antioxidative corn protein hydrolysates, purification and evaluation of three novel corn antioxidant peptides. Food Chem. 204, 427-436. doi: 10.1016/j.foodchem.2016.02.119

Källberg, M., Wang, H., Wang, S., Peng, J., Wang, Z., Lu, H., et al. (2012). Template-based protein structure modeling using the raptorX web server. Nat. Protoc. 7, 1511-1522. doi: 10.1038/nprot.2012.085

Kong, B., and Xiong, Y. L. (2006). Antioxidant activity of zein hydrolysates in a liposome system and the possible mode of action. J. Agric. Food Chem. 54, 6059-6068. doi: 10.1021/jf060632q

Kornienko, A., Rastogi, S. K., Lefranc, F., and Kiss, R. (2013). Therapeutic agents triggering nonapoptotic cancer cell death. J. Med. Chem. 56, 4823-4239. doi: $10.1021 / \mathrm{jm} 400136 \mathrm{~m}$

Landry, J., and Moureaux, T. (1987). Albumins and globulins in developing maize grains. Biochimie 69, 691-97. doi: 10.1016/0300-9084(87)90190-8

Li, H-M., Hu, X., Guo, P., Fu, P., Xu, L., and Zhang, X.-Z. (2010). Antioxidant properties and possible mode of action of corn protein peptides and zein peptides. J. Food Biochem. 34, 44-60. doi: 10.1111/j.1745-4514.2009.00292.x

Li, J.-T., Zhang, J.-L., He, H., Ma, Z.-L., Nie, Z.-K., Wang, Z.-Z., et al. (2013). Apoptosis in human hepatoma HepG2 cells induced by corn peptides and its anti-tumor efficacy in H22 tumor bearing mice. Food Chem. Toxicol. 51, 297-305. doi: 10.1016/j.fct.2012.09.038

Li, X.-X., Han, L.-J., and Chen, L.-J. (2008). In vitro antioxidant activity of protein hydrolysates prepared from corn gluten meal. J. Sci. Food Agric. 88, 1660-1666. doi: $10.1002 /$ jsfa.3264

Li, Y. L., Dai, X. R., Yue, X., Gao, X. Q., and Zhang, X. S. (2014). Identification of Small Secreted Peptides (SSPs) in Maize and expression analysis of partial SSP genes in reproductive tissues. Planta 240, 713-728. doi: 10.1007/s00425-014-2123-1

Lin, F., Chen, L., Liang, R., Zhang, Z., Wang, J., Cai, M., et al. (2011). Pilot-scale production of low molecular weight peptides from corn wet milling byproducts and the antihypertensive effects in vivo and in vitro. Food Chem. 124, 801-807. doi: 10.1016/j.foodchem.2010.06.099

Liu, R. H. (2007). Whole grain phytochemicals and health. J. Cereal Sci. 46, 207-219. doi: 10.1016/j.jcs.2007.06.010

Lv, J., Nie, Z.-K., Zhang, J.-L., Liu, F.-Y., Wang, Z.-Z., Ma, Z.-L., et al. (2013). Corn peptides protect against thioacetamide-induced hepatic fibrosis in rats. J. Med. Food 16, 912-919. doi: 10.1089/jmf.2012.2626

Ma, Z. L., Zhang, W. J., Yu, G. C., He, H., and Zhang, Y. (2012). The primary structure identification of a corn peptide facilitating alcohol metabolism by HPLC-MS/MS. Peptides 37, 138-143. doi: 10.1016/j.peptides.2012.07.004
Ma, Z. T. H., Shi, W., Liu, W., and He, H. (2015). Inhibition of hepatocyte apoptosis: an important mechanism of corn peptides attenuating liver injury induced by ethanol. Int. J. Mol. Sci. 16, 22062-22080. doi: 10.3390/ijms160922062

Malaguti, M., Dinelli, G., Leoncini, E., Bregola, V., Bosi, S., Cicero, A. F. G., et al. (2014). Bioactive peptides in cereals and legumes: agronomical, biochemical and clinical aspects. Int. J. Mol. Sci. 15, 21120-21135. doi: 10.3390/ijms151121120

McConnell, E. J., Devapatla, B., Yaddanapudi, K., and Davis, K. R. (2015). The soybean-derived peptide lunasin inhibits non-small cell lung cancer cell proliferation by suppressing phosphorylation of the retinoblastoma protein. Oncotarget 6, 4649-4662. doi: 10.18632/oncotarget.3080

McDermott, A. (2009). Bioactive peptides. Funct. Nutraceuticals 3, 357-401. doi: 10.1007/978-1-4614-3480-1_3

Momany, F. A., Sessa, D. J., Lawton, J. W., Selling, G. W., Hamaker, S. A., and Willett, J. L. (2006). Structural characterization of $\alpha$-Zein. J. Agric. Food Chem. 54, 543-547. doi: 10.1021/jf058135h

Ortiz-Martinez, M., Gonzalez de Mejia, E., García-Lara, S., Aguilar, O., LopezCastillo, L. M., and Otero-Pappatheodorou, J. T. (2017). Antiproliferative effect of peptide fractions isolated from a quality protein maize, a white hybrid maize, and their derived peptides on hepatocarcinoma human HepG2 Cells. J. Funct. Foods 34, 36-48. doi: 10.1016/j.jprot.2014.03.044

Ortiz-Martinez, M., Winkler, R., and García-Lara, S. (2014). Preventive and therapeutic potential of peptides from cereals against cancer. J. Proteomics 111, 165-83. doi: 10.1016/j.jff.2017.04.015

Parris, N., Moreau, R. A., Johnston, D. B., Dickey, L. C., and Aluko, R. E. (2008). Angiotensin I converting enzyme-inhibitory peptides from commercial wet- and dry-milled corn germ. J. Agric. Food Chem. 56, 2620-2623. doi: 10.1021/jf072238d

Puchalska, P. M., Marina, L., and García, C. M. (2013). Development of a high-performance liquid chromatography-electrospray ionizationquadrupole-time-of-flight-mass spectrometry methodology for the determination of three highly antihypertensive peptides in maize crops. J. Chromatogr. A 1285, 69-77. doi: 10.1016/j.chroma.2013.02.015

Rost, B. (2003). The predictprotein server. Nucleic Acids Res. 31, 3300-3304. doi: 10.1093/nar/gkg508

Sarmadi, B. H., and Ismail, A. (2010). Antioxidative peptides from food proteins: a review. Peptides 31, 1949-1956. doi: 10.1016/j.peptides.2010.06.020

Shukla, R., and Cheryan, M. (2001). Zein: the industrial protein from corn. Ind. Crops Prod. 13, 171-192. doi: 10.1016/S0926-6690(00)00064-9

Tang, M., He, X., Luo, Y., Ma, L., Tang, X., and Huang, K. (2013). Nutritional assessment of transgenic lysine-rich maize compared with conventional quality protein maize. J. Sci. Food Agric. 93, 1049-1054. doi: 10.1002/jsfa.5845

Tang, N., and Zhuang, H. (2014). Evaluation of antioxidant activities of zein protein fractions. J. Food Sci. 79, C2174-C2184. doi: 10.1111/1750-3841.12686

Tang, X., He, Z., Dai, Y., Xiong, Y. L., Xie, M., and Chen, J. (2010). Peptide fractionation and free radical scavenging activity of zein hydrolysate. J. Agric. Food Chem. 58, 587-593. doi: 10.1021/jf9028656

Thanan, R., Oikawa, S., Hiraku, Y., Ohnishi, S., Ma, N., Pinlaor, S., et al. (2014). Oxidative stress and its significant roles in neurodegenerative diseases and cancer. Int. J. Mol. Sci. 16, 193-217. doi: 10.3390/ijms16010193

Tnani, H., López-Ribera, I., García-Muniz, N., and Vicient, C. M. (2013). ZmPTR1, a maize peptide transporter expressed in the epithelial cells of the scutellum during Germination. Plant Sci. 207, 140-47. doi: 10.1016/j.plantsci.2013.03.005

Wall, J. S., Cooker, L. A., and Bietz, J. A. (1988). Structure and origin of maize endosperm alcohol-insoluble glutelin. J. Agric. Food Chem. 36:722. doi: $10.1021 /$ jf00082a012

Wang, L., Ding, L., Wang, Y., Zhang, Y., and Liu, J. (2015). Isolation and characterisation of in vitro and cellular free radical scavenging peptides from corn peptide fractions. Molecules 20, 3221-3237. doi: 10.3390/molecules20023221

Wang, L., Ding, L., Yu, Z., Zhang, T., Ma, S., and Liu, J. (2016). Intracellular ROS scavenging and antioxidant enzyme regulating capacities of corn gluten meal-derived antioxidant peptides in HepG2 cells. Food Res. Int. 90, 33-41. doi: 10.1016/j.foodres.2016.10.023

Wang, L., Xu, C., Qu, M., and Zhang, J. (2008). Kernel Amino acid composition and protein content of introgression lines from Zea Mays Ssp. mexicana into cultivated maize. J. Cereal Sci. 48, 387-393. doi: 10.1016/j.jcs.2007.09.014 
Wang, X.-J., Zheng, X.-Q., Kopparapu, N.-K., Cong, W.-S., Deng, Y.-P., Sun, X.-J., et al. (2014). Purification and evaluation of a novel antioxidant peptide from corn protein hydrolysate. Process Biochem. 49, 1562-1569. doi: 10.1016/j.procbio.2014.05.014

Wang, Y., Chen, H., Wang, J., and Xing, L. (2014). Preparation of active corn peptides from zein through double enzymes immobilized with calcium alginate-chitosan beads. Process Biochem. 49, 1682-1690. doi: 10.1016/j.procbio.2014.07.002

WHO (2017). Cancer. WHO Media Centre. Available online at: http://www.who.int/mediacentre/factsheets/fs297/en/.

Wu, Y., Pan, X., Zhang, S., Wang, W., Cai, M., Li, Y., et al. (2014). Protective effect of corn peptides against alcoholic liver injury in men with chronic alcohol consumption: a randomized double-blind placebo-controlled study. Lipids Health Dis. 13:192. doi: 10.1186/1476-511X-13-192

Yang, Y., Tao, G., Liu, P., and Jia, L. (2007). Peptide with Angiotensin I-converting enzyme inhibitory activity from hydrolyzed corn gluten meal. J. Agric. Food Chem. 55, 7891-7895. doi: 10.1021/jf0705670

Yu, G. C., Li, T. J., He, H., Huang, W. H., and Zhang, W. J. (2013). Ultrafiltration preparation of potent bioactive corn peptide as alcohol metabolism stimulator in vivo and study on its mechanism of action. J. Food Biochem. 37, 161-167. doi: 10.1111/j.1745-4514.2011.00613.x

Yu, G.-C., Lv, J., He, H., Huang, W., and Han, Y. (2012). Hepatoprotective effects of corn peptides against carbon tetrachloride-induced liver injury in mice. J. Food Biochem. 36, 458-464. doi: 10.1111/j.1745-4514.2011.00551.x

Zambrowicz, A., Timmer, M., Polanowski, A., Lubec, G., and Trziszka, T. (2013). Manufacturing of peptides exhibiting biological activity. Amino Acids 44, 315-320. doi: 10.1007/s00726-012-1379-7

Zhang, B., Luo, Y., and Wang, Q. (2011). Effect of acid and base treatments on structural, rheological, and antioxidant properties of $\alpha$-zein. Food Chem. 124, 210-220. doi: 10.1016/j.foodchem.2010.06.019

Zhang, Z., Ma, H., Wang, X., Zhao, Z., Zhang, Y., Zhao, B., et al. (2016). A tetrapeptide from maize protects a transgenic Caenorhabditis elegans A $\beta$ 1-42 model from $A \beta$-induced toxicity. RSC Adv. 6, 56851-56858. doi: 10.1039/C6RA06130C
Zheng, X. Q., Li, L. T., Liu, X. L., Wang, X. J., Lin, J., and Li, D. (2006). Production of hydrolysate with antioxidative activity by enzymatic hydrolysis of extruded corn gluten. Appl. Microbiol. Biotechnol. 73, 763-770. doi: 10.1007/s00253-006-0537-9

Zhou, C., Hu, J., Ma, H., Yagoub, A. E., Yu, X., Owusu, J., et al. (2015). Antioxidant peptides from corn gluten meal: orthogonal design evaluation. Food Chem. 187, 270-278. doi: 10.1016/j.foodchem.2015.04.092

Zhou, C., Ma, H., Ding, Q., Lin, L., Yu, X., Luo, L., et al. (2013). Ultrasonic pretreatment of corn gluten meal proteins and neutrase: effect on protein conformation and preparation of ACE (Angiotensin Converting Enzyme) inhibitory peptides. Food Bioprod. Process. 91, 665-671. doi: 10.1016/j.fbp.2013.06.003

Zhou, K., Sun, S., and Canning, C. (2012). Production and functional characterisation of antioxidative hydrolysates from corn protein via enzymatic hydrolysis and ultrafiltration. Food Chem. 135, 1192-1197. doi: 10.1016/j.foodchem.2012.05.063

Zhuang, H., Tang, N., and Yuan, Y. (2013). Purification and identification of antioxidant peptides from corn gluten meal. J. Funct. Foods 5, 1810-1821. doi: 10.1016/j.jff.2013.08.013

Zitvogel, L., Galluzzi, L., Smyth, M. J., and Kroemer, G. (2013). Mechanism of action of conventional and targeted anticancer therapies: reinstating immunosurveillance. Immunity 39, 74-88. doi: 10.1016/j.immuni.2013.06.014

Conflict of Interest Statement: The authors declare that the research was conducted in the absence of any commercial or financial relationships that could be construed as a potential conflict of interest.

Copyright $\odot 2017$ Díaz-Gómez, Castorena-Torres, Preciado-Ortiz and García-Lara. This is an open-access article distributed under the terms of the Creative Commons Attribution License (CC BY). The use, distribution or reproduction in other forums is permitted, provided the original author(s) or licensor are credited and that the original publication in this journal is cited, in accordance with accepted academic practice. No use, distribution or reproduction is permitted which does not comply with these terms. 